\title{
A Journey Toward Oxbow Lake Formation and Associated Change in Human Mosaic: Study on Kalindri River of Malda District
}

\author{
Dr. Swades Pal ${ }^{1}$, Shyamal Kumar $\mathrm{Kar}^{2}$ \\ ${ }^{1}$ Assistant Professor, Deptt. of Geography, University of Gour Banga, West Bengal \\ ${ }^{2}$ Research Scholar, Deptt. of Geography, Visva-Bharati, West Bengal
}

\begin{abstract}
This paper aims to illustrate the phases of oxbow lake formation in Kalindri river adjacent of Naogharia region and how over time being these oxbow lakes have converted into wetlands of multifaceted resource pools. At the same time it is also being attempted to show how the dynamics of river course is entangled with dynamism of population migration, settlement shifting, occupational shifting, and change of economic activities. Consultations of some old maps, local peoples' perceptions, time to time field survey etc. have done to prepare this article. It is found that two successive oxbow lakes formation and frequent over spilling events have direct impact on shifting of higher class population and settlement but the soil Childs are more interested to adjust with the situation. Poor sections of people have been adjusting themselves with changing physical setup and they have no anguish for frequent rehabilitation. Process of oxbow lake formation has also generated an excellent fertile land and which is considered to be a agricultural hotspot. Similarly, formation of oxbow lake wetland has generated good livelihood stability with ample opportunities of fishing, shelling, crabbing, hydrophytic vegetable production, wetland based irrigation non monsoon agriculture practices etc.
\end{abstract}

Keywords: River shifting, Oxbow lake formation, Oxbow lake wetland, Settlement shift, Livelihood generation, Formation of fertile land, Land use change, Agricultural intensification.

\section{Introduction}

Oxbow lake is a river cutoff due to high degree of bend and nearness of meander's limb in very closer to each other (Oxford Dictionary, Webster Dictionary). The process of cutoff may be chute cut or neck cut but ultimately it produce oxbow lake (Strahler and Strahler, 1996). River flood plains containing rivers with a highly sinuous platform will be populated by longer oxbow lakes than those with low sinuosity. This is because rivers with high sinuosity will have larger meanders and greater opportunity for longer lakes to form. Rivers with lower sinuosity are characterized by fewer cutoffs and shorter oxbow lakes due to the shorter distance of their meanders (Constantine and Thomas, 2008, Hickin, 2002). In river Mississippi river there is 208 oxbow lakes. These shifts occur every thousand years or so, especially in the lower parts of the river, through a process known as delta switching, or avulsion: when the river flow is slow, the sedimentation clogs the river channel and it eventually finds another channel.

River course shifting, meander formation, oxbow lake formation, transformation of oxbow lake into semi flowing and ultimately stagnant wetland are very common events of environment. Man's duty is to adjust or readjust their life and livelihood with changing drainage conditions. Such types of shifting may provide barrier against accessibility or may remove the barrier. It is true that this kind of shifting and oxbow lake formation provides some economic possibilities like increase fertility of soil, renewal of soil fertility, fishing potentiality, potentiality of aquaculture, irrigation potentialities, animal resources etc. So, instead of rigid livelihood, if people think alternative potential provision, solution will easily be achievable. This area is characterized by a typical types of settlement in accordance with frequent possibility of over spilling, land instability etc. Approach of people toward adaption of the changing condition plays vital role to find out proper solution. Views and reaction of this course shift, loss of existing physical setup, formation of new resource base etc. are highly different because different section of people belongs to different socio economic groups and linkages with this changing condition are diversified. However, the views and reactions toward the positioning of oxbow lake in form of wetland possesses are diversified. Barbier (1989b, 1993, 1994) and Scodari (1990) etc. economically evaluated the cost of the benefits derived from this kind of wetland.

This paper aims to find out the historical journey of oxbow lake formation, creation of resource base in changing set up, how people's stability, stability of settlement of different socio-economic groups are linked with changing physical setup and associated changes. 


\section{Study Area}

The Kalindri is considered as a distributary of the eastern branch of the Ganges but actually it is a branch of the river Mahananda, which by the name of Phulher or Phulahar, passes through the district of Purnea in Bihar and enters Malda district near Mihaghat (J.L. No.162 in Harishchandrapur P.S.) from where it is known as the Kalindri. It is flowing mainly in the south-eastern direction to its confluence win the Mahananda opposite the town of Old Malda. The flood waters of the Ganges pass down the Kalindri which ultimately empties itself into the Mahanda near Old Malda. In James Rennell's map, the river was shown simply as an offshoot of the eastern branch of the Ganges taking off about $3 \mathrm{~km}$. northwest of Ratua P.S. In Hunter's account and also in the District Gazetteer by Lamboun (1918), it is stated that the main body of its waters are brought down from the mountains of Nepal by the Panar River which assumes the name of Kalindri shortly before its entry into the district. But Buchanan Hamilton (1810), on the other hand, considered that the portion of the river lying in this district was nothing more than a branch of the Ganges. Ashok Mitra support Hamilton's views in the 1951 District Handbook. Probably the river became continuous later on. But at the time when Buchanan Hamilton wrote, the position of the Ganges was substantially the same as it is now. At the point where the Ganges first touches the district as it sweeps round the Rajmahal Hills it is connected in the rains by a navigable channel down which the flood waters of the Ganges find a way when the main channel of the Ganges is below Rajmahal at present, the channel in the east of the 'Bhutni Diara' becomes shallow and large sandy 'Chara' from on that side of the river. Consequently when the level of the Ganga drops at the end of the rainy season its water is prevented by sandbars from floing into the mouth of the channel. The Kalindri, thus, empties itself into the Mahananda and in hot and dry weather its bed is nothing more than series of pools. The Kalindri flowing mainly eastward divides the western part of the district into two district portions. As mentioned earlier, the portion to the north of this river has been distinguished as 'Tal' land and the portion to the south as 'Diara'. The later is the most fertile and hence the most populous areas of the district. The Kalindri receives as its tributaries the Kalkos, Kankar, Kos and Baromasia in the north. These four small streams cause heavy floods during the rainy season as they rise, but drain the entire 'Tal' land. During the summer and winter they almost dry up. The changes in to course of the river Kalindri occasionally cause erosion to the English Bazar- Mathurapur Road. This river is navigable during the rainy season and fordable in dry summer. The great depletion of the 'Tal' land clearly indicates that it must have been a river bed at one time, for along the whole length of the 'Tal' these are large swamps and 'Beel's which only recently have been reclaimed for cultivation.

A series of oxbow lake in Kalindri river near Naugharia village is the prime interest of study. Two successive oxbow lakes at same curvature at the left hand side and another oxbow lake at the right hand side just few $\mathrm{km}$. upstream are located. Over spilling events are majorly responsible for landform building in the surrounding area. Similarly, due to frequent shifting of river courses, public land properties are captured. Excessive siltation in course and off course regulates the connectivity between rejected channel and current course.

Both Hindu and Muslim population are coexist in this region. Economic status is fairly good.

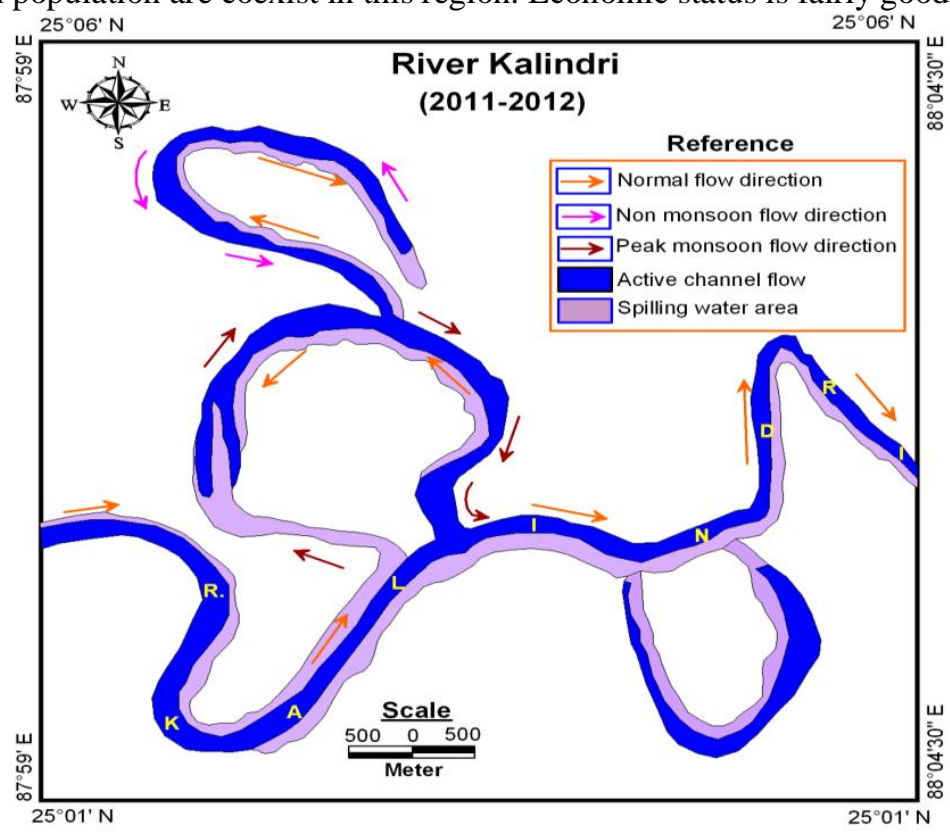

Fig. 1 


\section{Materials And Methods}

Toposheets of Survey of India of different periods, Satellite images etc. have consulted to prepare the base map of different periods. Empirical field survey has conducted to collect collateral materials and witness of river shifting, land use shifting, crop pattern shift, population migration, settlement shift, change of crop productivity, evaluation of existing resource base, livelihood dependency and process of human adjustment with changing conditions etc.

\subsection{Phases of Oxbow Lake Formation \\ 4.1.1 Phase I (1916-17)}

IV. Results And Analysis

There is a long history of to attain the phase I condition before this considered phase I. There are some bents within $1^{\text {st }}$ and $2^{\text {nd }}$ oxbow lakes, sometimes they are continuous or partially dissected, somewhere is existing as waterlogged channel and somewhere it is captured by man for agriculture or settlement purpose; there is interwoven wet and dry course. Presence of all these proved that the complexity of the Kalindri river course evolution. In considered phase I, the degree of bend is so winding and acute that rejection of highly close neck arcute course is very feasible( $\left(1^{\text {st }}\right.$ oxbow). Similarly, $2^{\text {nd }}$ bend is also taking same shape to leave oxbow lake in near time. Sinuosity index (SI) in this phase is very high ( $\mathrm{SI}=3.05)$.

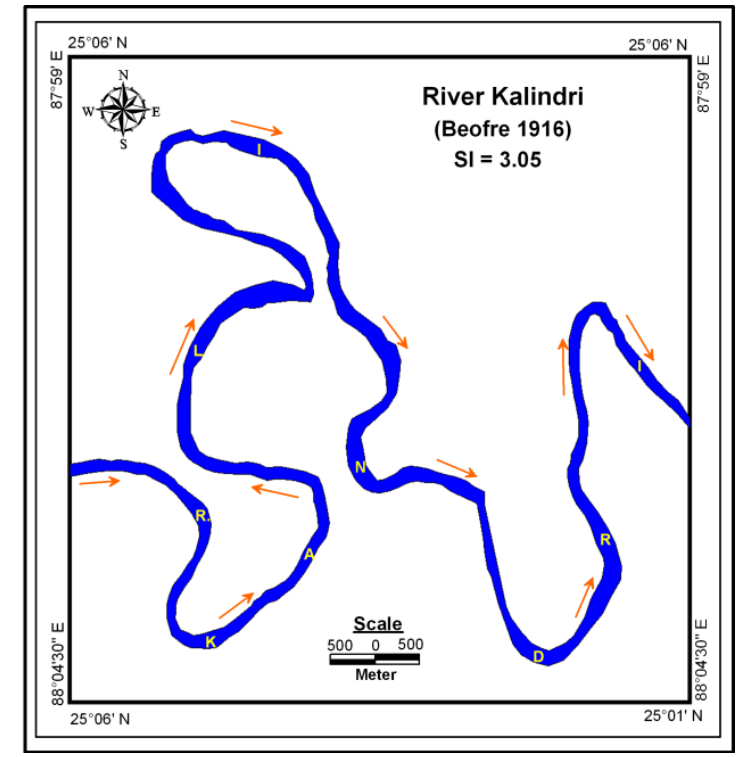

Fig. 2

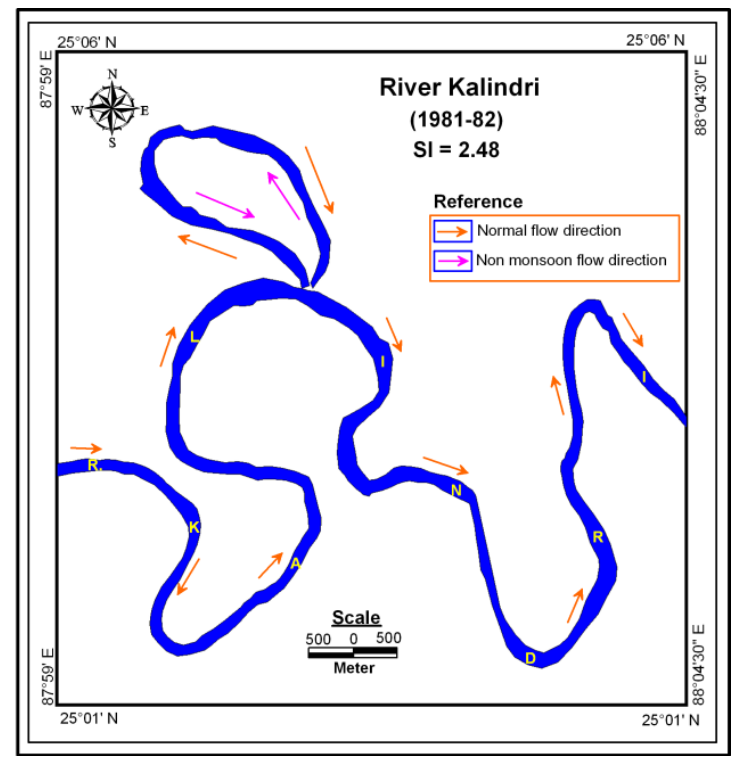

Fig. 3

\subsubsection{Phase II (1981-82)}

In phase II, the extreme bend of the river has cut off from main stream and rejected channel forms an oxbow lake as well as a wetland. Just after cutting off the $1^{\text {st }}$ oxbow lake energy of the active channel flow has raised and this condition again ensured the proceeding of $2^{\text {nd }}$ oxbow lake formation. In cutoff channel, during monsoon water enters through the inlet and drains out in another wing of the cutoff channel (outlet). As gradually, the exit portion of the channel becomes elevated and detached from main channel; during post monsoon period water from cutoff channel is returned to the main channel through inlet. In this semi active channel condition, total width of the cutoff channel has increased and new land within the oxbow lake has started to build up.

\subsubsection{Phase III (1968-69)}

Phase III shows that a large part of the outlet of the $1^{\text {st }}$ oxbow lake has dried up and this part has also become elevated. One way inflow and outflow both during monsoon and pre monsoon periods is confirmed due to complete choking of outlet. At the same time $2^{\text {nd }}$ oxbow lake takes birth due to straightening of current river. Not only that over time being, entrance of the lake gets clogging and up to a large part of the entrance reach is affected in this process. During monsoon period when water level of the current river raises up to elevated entrance level, some amount of river water enter into the $2^{\text {nd }}$ oxbow. During normal monsoon, no water supply it gets from main channel. Existing monsoonal storage of water from both $1^{\text {st }}$ and $2^{\text {nd }}$ oxbow lakes and water of the surrounding areas drain though the outlet of the $2^{\text {nd }}$ oxbow lake. In this phase another major event which has happened is the formation of a new oxbow lake at the right hand side in more downstream course of the present 
oxbow lakes. As both inlet and outlet of this oxbow lake have demolished, it has converted into mere stagnant water body.

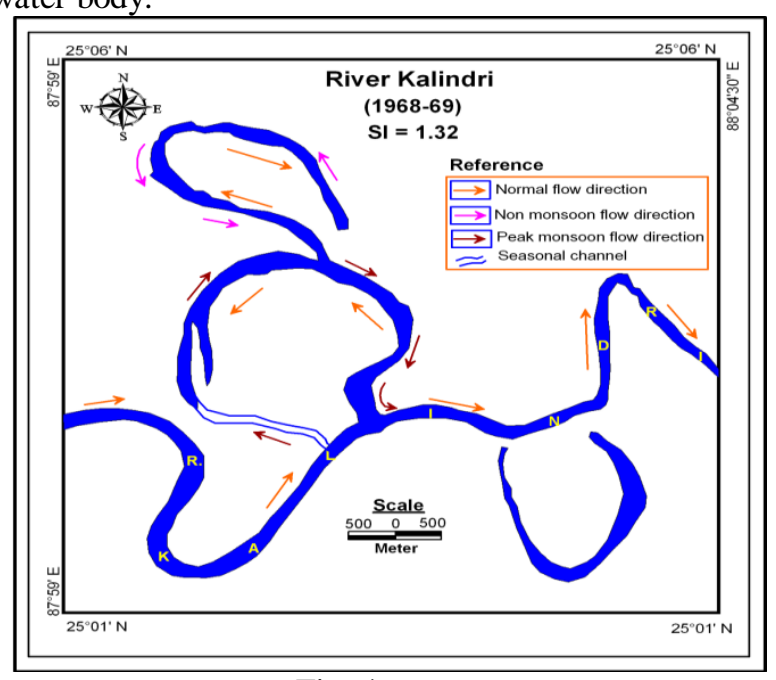

Fig. 4

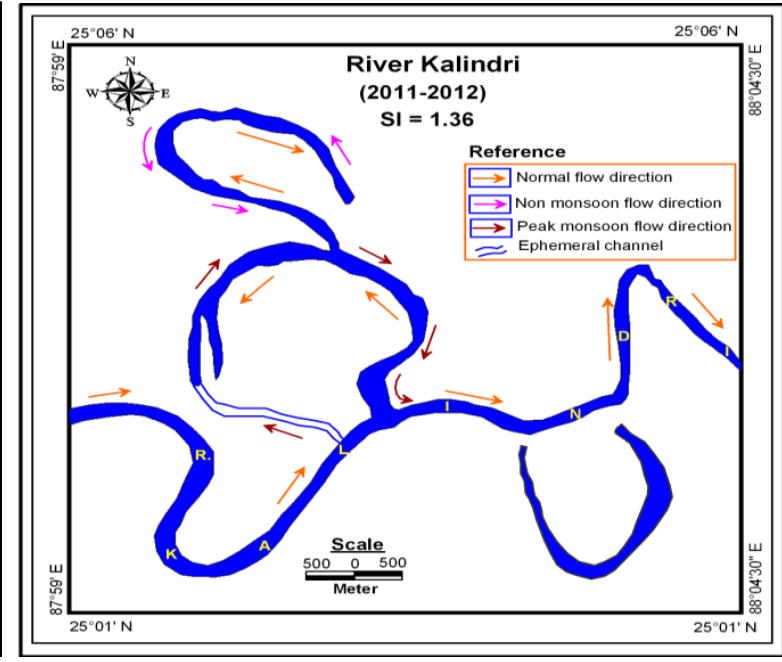

Fig. 5

\subsubsection{Phase IV (2012)}

In present state more part of the entrance of $2^{\text {nd }}$ cutoff has choked and dried up. Flow pattern is as usual in previous state. Land building activities has been going on within the interior parts oxbow lakes but cliff slope of the oxbow lakes is prone to erosion and expansion and therefore original width of the channels has been widening out. In this connection it should be mentioned that over spilling area has been squeezing slowly. Reduction of water volume in river is not the sole cause behind this diminishing tendency of over spilling but pattern of newly built land slope is also restricting this condition. Drying up of the inlet part of the $2^{\text {nd }}$ oxbow lake has reduced the chance of another oxbow lake just before present oxbow because dried up limb of the $2^{\text {nd }}$ oxbow was very nearer to the current channel.

Table 1: Sinuosity Indices in Different Phases of Oxbow Lake Formation

\begin{tabular}{|l|l|l|l|l|}
\hline Phases & Phase I (1916) & $\begin{array}{l}\text { Phase II (1981- } \\
82)\end{array}$ & Phase II (1968-69) & $\begin{array}{l}\text { Phase II } \\
(2012)\end{array}$ \\
\hline Sinuosity Index & 3.05 & 2.48 & 1.32 & 1.36 \\
\hline
\end{tabular}

\subsection{Shifting of Channel Thalweg}

In any meandering stream, tendency of thalweg shift is very common phenomena (Ref).

\subsubsection{Analysis on Current Active Course}

Within last 60 years, the thalweg of the present active channel has shifted up to $43 \mathrm{~m}$. Actually broad channel width of current course is more than $210 \mathrm{~m}$. Thalweg has been shifting from right side to left and with course of shifting, the fertile land is developing at the right hand side of the channel. This newly developed land has been characterizing this channel in new morphological manner. For example, entrenchment ratio of the channel has been increasing. There is more chance to shift the thalweg more left with shifting of channel toward same direction. This tendency also ensures that river course will be shifted further in same direction. Certainly, as the channel has straightened, the rate of shifting will be quite less.

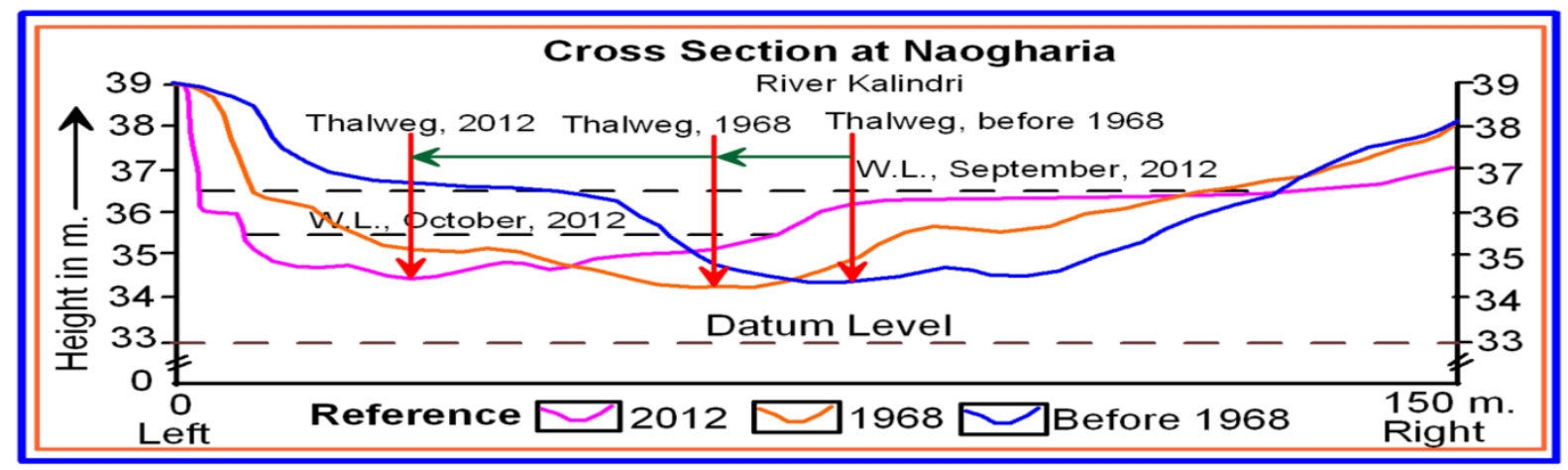

Fig. 6 


\subsubsection{Analysis on $1^{\text {st }}$ Oxbow Course}

In $1^{\text {st }}$ oxbow lake this kind of evidence of thalweg shifting is found. As per peoples' perception, the rejected channel has been shifting left even after closing of outlet. Of course, the rate has slowed down at present after such closing. In last 60 years, total thalweg shifting is about $26 \mathrm{~m}$. Cliff slope of the oxbow hinders erosion but it is going on at present also.

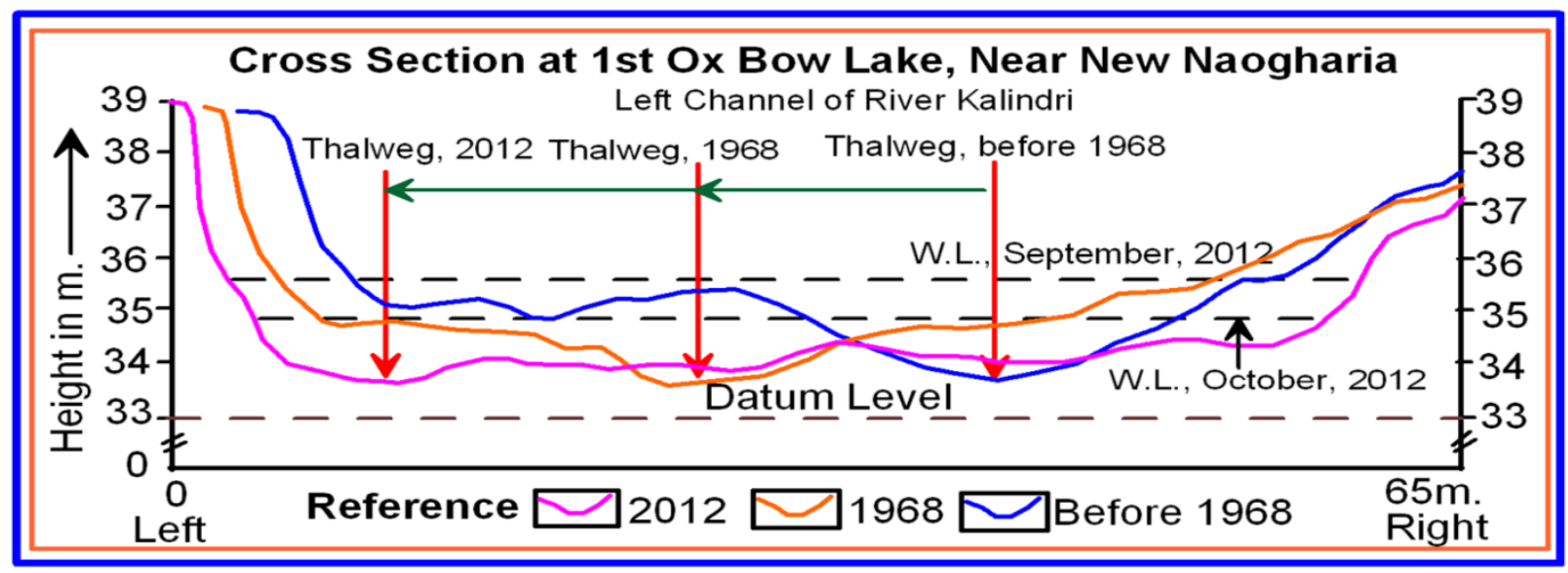

\subsection{Present Hydrological Scenario}

Fig. 7

\subsubsection{Conversion of River to Wetland}

Loss of either inlet or outlet of the oxbow lakes has converted the flowing lakes into stagnant wetland. The serial procedure of wetland formation has been described at the first section of the paper.

\subsubsection{Economic Potentiality of the Wetland}

Wetland is considered as resource pool, biodiversity hotspot, recharge zone, good fishing ground, irrigation pool and so many visible and invisible resource storage. So, if one evaluate all these resources in monetary terms the value would be much greater than any other agriculturally productive land. In this section, an attempt has been taken to evaluate some of the major direct resources which are available in the present condition of wetlands.

In table 2 wetland characteristics have been depicted in aim to evaluate the wetlands. Although hydrological regime of the $1^{\text {st }}$ oxbow cum wetland is less still water availability in this wetland is less than $2^{\text {nd }}$ wetland. Areal extent of the former oxbow and more depth of water in the same is the main cause behind this difference of water retention capacity.

\begin{tabular}{|c|c|c|c|c|c|}
\hline \multirow[t]{2}{*}{ Wetland } & \multirow[t]{2}{*}{$\begin{array}{l}\text { Cross sectional } \\
\text { area (sq.m.) }\end{array}$} & \multirow{2}{*}{$\begin{array}{l}\text { Potential water } \\
\text { holding capacity } \\
\text { (cubic meter) }\end{array}$} & \multirow[t]{2}{*}{$\begin{array}{l}\text { Hydrological } \\
\text { regime }\end{array}$} & \multicolumn{2}{|c|}{$\begin{array}{l}\text { Actual water availability } \\
\text { (cubic meter) }\end{array}$} \\
\hline & & & & Monsoon & Premonsoon \\
\hline $\begin{array}{l}\text { Oxbow } \\
\text { lake I }\end{array}$ & $\begin{array}{l}\mathrm{L}=5300 \mathrm{~m} \\
\mathrm{~W}=65 \mathrm{~m} . \\
\mathrm{A}=344500\end{array}$ & $\begin{array}{l}\mathrm{D}=1.78 \mathrm{~m} \\
613210\end{array}$ & $\begin{array}{l}\text { Permanent } \\
0.7 \mathrm{~m} \text {. seasonal } \\
\text { regime }\end{array}$ & $\begin{array}{l}\mathrm{WD}=1.33 \mathrm{~m} . \\
\mathrm{AW}=458185\end{array}$ & $\begin{array}{l}\mathrm{WD}=0.73 \mathrm{~m} \\
\mathrm{AW}=251485\end{array}$ \\
\hline $\begin{array}{l}\text { Oxbow } \\
\text { lake II }\end{array}$ & $\begin{array}{l}\mathrm{L}=5700 \mathrm{~m} . \\
W=71 \mathrm{~m} . \\
\mathrm{A}=404700\end{array}$ & $\begin{array}{l}\mathrm{D}=1.88 \mathrm{~m} \\
760836\end{array}$ & $\begin{array}{l}\text { Permanent } \\
0.90 \mathrm{~m} \text {. seasonal } \\
\text { regime }\end{array}$ & $\begin{array}{l}\mathrm{WD}=1.36 \mathrm{~m} . \\
\mathrm{AW}=550392\end{array}$ & $\begin{array}{l}\mathrm{WD}=0.46 \mathrm{~m} \\
\mathrm{AW}=186162\end{array}$ \\
\hline
\end{tabular}

Note: $\mathrm{L}=$ Length; $\mathrm{W}=\mathrm{Wid}$ th; $\mathrm{D}=\mathrm{Depth} ; \mathrm{A}=$ Cross sectional area; $\mathrm{WD}=$ Water depth

Table 3: Ecoñomic Earning

\begin{tabular}{|l|l|l|l|l|l|}
\hline Wetland & \multicolumn{3}{|c|}{ Direct Earning } & \multicolumn{2}{c|}{ Indirect earning } \\
\hline & Fishing (Rs./ha) & $\begin{array}{l}\text { Other animal } \\
\text { resources } \\
\text { (Rs.ha) }\end{array}$ & $\begin{array}{l}\text { Vegetables } \\
\text { (Rs./ha) }\end{array}$ & $\begin{array}{l}\text { Irrigation Water } \\
\text { (m³ in each ha) }\end{array}$ & $\begin{array}{l}\text { Recharge of } \\
\text { water }\end{array}$ \\
\hline $\begin{array}{l}\text { Oxbow } \\
\text { lake I }\end{array}$ & $\begin{array}{l}56000 \text { natural } \\
\text { fishing; } 96000- \\
102000 \text { for fish } \\
\text { seeding }\end{array}$ & 9800 & $\begin{array}{l}5100 \text { for } \\
\text { natural; } 14500 \\
\text { for cultivated }\end{array}$ & 730 & \\
\hline $\begin{array}{l}\text { Oxbow } \\
\text { lake II }\end{array}$ & $\begin{array}{l}\text { 8400 natural } \\
\text { fishing; 12000- } \\
16000 \text { for fish } \\
\text { seeding }\end{array}$ & 9300 & $\begin{array}{l}5100 \text { for } \\
\text { natural; } 14500 \\
\text { for cultivated }\end{array}$ & 730 & $\begin{array}{l}14 \% \text { of } \\
\text { total stagnant }\end{array}$ \\
\hline
\end{tabular}


Total valuation of wetland using only some crude benefits in a year is about Rs. 70000 to Rs.160000 per hectare excluding the cost of irrigation water, recharge volume, biodiversity values etc.

\subsection{Economic Evaluation of the Surrounding Area}

Total selected area of this study area is 36 sq.km. With journey of river course shift and land evolution, some changed has incurred in land use pattern. Although, there is fertile agriculture land, high productivity capacity of land still these lands have gradually been converting into mango orchard. Of course this conversion does not bring any negative impact on economy because per hectare monetary return is excessively high in case of mango orchard. Not only that, peasants have been accommodating dual farming to ensure more land value. Simultaneously, they practice both mango cultivation and some crops like pulses, mulberry, vegetables sometimes aman or aus paddy. Commercialization of mango, familiarity of mango cultivation etc. have encouraged people to shift from sole crop cultivation to combination of mango and other crops. In this context of land use change, it should be mentioned that although sole agricultural land or crop land has declined in total acreage from previous time to present but extension of agricultural practice within mango orchard has increased substantially. Per hectare outcome from oxbow lake has been mentioned in the earlier section. Sole crop land yields Rs. 60000 to 85000 per hectare in a year. Amount of yield depends on the nature of crop. Land produces both mango and crops whose per hectare monetary return is more than Rs. 100000 to Rs. 150000 . Here is the proper justification of readjustment of people with existing physical setup and inaccessibility.

Table 4: Land use Shift

\begin{tabular}{|l|r|r|r|r|l|}
\hline \multirow{2}{*}{ Land use pattern } & \multicolumn{2}{|c|}{1960} & \multicolumn{2}{|c|}{2012} & \multirow{2}{*}{ Remarks } \\
\cline { 2 - 5 } & Area in sq.km. & $\%$ to total area & $\begin{array}{l}\text { Area in } \\
\text { sq.km. }\end{array}$ & $\begin{array}{l}\text { \% to total } \\
\text { area }\end{array}$ & \\
\hline Water body & 2.12 & 5.82417582 & 3.2 & 8.79120879 & 2.967032967 \\
\hline Crop land & 11.39 & 31.2912088 & 5.8 & 15.9340659 & -15.3571429 \\
\hline Mango orchard & 21.73 & 59.6978022 & 26.1 & 71.7032967 & 12.00549451 \\
\hline Settlement & 1.16 & 3.18681319 & 1.3 & 3.57142857 & 0.384615385 \\
\hline Total & 36.4 & 100 & 36.4 & 100 & \\
\hline
\end{tabular}

Source: Cadastral plot evaluation, people's perception, presents field study

\subsection{Soil Quality Assessment}

Most part of the study area is developed by continuous over spilling of river and therefore the entire land composed with thick and fertile silt. This land is so fertile that it requires less chemical fertilizers. High level soil moisture also supports good crop cultivation. Silt deposition rate is fast that within last 60 years more than 3 meters thick land has appeared at the outlet of $1^{\text {st }}$ oxbow lake. A fertile new land gently sloping toward oxbow lake has emerged within the inner periphery of $1^{\text {st }}$ oxbow lake. This newly emerged land is highly productive and estimated land value is also Rs. 22,00000/hectare (One bigha @ Rs.3,00000). In spite of physical barrier, transport inaccessibility, the people who have direct linkages with agriculture are reluctant to migrate to some other places where so called barrier would be overcome and other amenities could be enjoyed.

\subsection{Shift of Cropping Pattern}

Cropping intensity has increased to some extent in last 50 years but sole crop cultivated area has decreased alarmingly. Off record extension of agricultural land in the mango orchard area is a positive sign of agricultural development. Pulses cultivation has intensified and this cultivation captured most part of the mango orchard. Prestigious mulberry culture is glowing off over time due growing problem. Fallow land reclamation has added a good dimension in agricultural economy. It should also be mentioned that per hectare productivity has increased significantly at present. In general, expenditure for cultivation has increased disproportionately with profit. But, as this land itself possesses good level of fertility, water availability come from river or oxbow lakes, level of expenditure is to some extent less in this study area. Both the referenced time describe multi-crop practices but at present the state is quite better due to dispersion of agricultural area among different crops (see table 6). Crop combination value is nearer to 1 indicates good state of crop combination. Crop diversity has also raised from 0.68 to 0.84 according to Entropy Index (EI). 


\begin{tabular}{|c|c|c|c|c|c|c|c|c|c|c|c|}
\hline \multicolumn{3}{|c|}{ Monsoon, 1968} & \multicolumn{3}{|c|}{ Pre monsoon, 1968} & \multicolumn{3}{|c|}{ Monsoon, 2012} & \multicolumn{3}{|c|}{ Pre monsoon, 2011} \\
\hline Crop & $\begin{array}{l}\text { Area in } \\
\mathrm{sq} . \mathrm{km}\end{array}$ & $\begin{array}{l}\% \text { of } \\
\text { area to } \\
\text { total }\end{array}$ & Crop & $\begin{array}{l}\text { Area } \\
\text { in } \\
\mathrm{sq} . \mathrm{km} .\end{array}$ & $\begin{array}{l}\% \text { of } \\
\text { area to } \\
\text { total }\end{array}$ & Crop & $\begin{array}{l}\text { Area } \\
\text { in } \\
\mathrm{sq} \cdot \mathrm{km} .\end{array}$ & $\begin{array}{l}\% \text { of } \\
\text { area to } \\
\text { total }\end{array}$ & Crop & $\begin{array}{l}\text { Area } \\
\text { in } \\
\mathrm{sq} \cdot \mathrm{k} \\
\mathrm{m} . \\
\end{array}$ & $\begin{array}{l}\% \text { of } \\
\text { area } \\
\text { to } \\
\text { total } \\
\end{array}$ \\
\hline $\begin{array}{l}\text { Aman } \\
\text { paddy }\end{array}$ & 5.42 & 47.59 & $\begin{array}{l}\text { Boro } \\
\text { paddy }\end{array}$ & 0.83 & 7.29 & $\begin{array}{l}\text { Aman } \\
\text { paddy }\end{array}$ & 1.46 & 25.17 & $\begin{array}{l}\text { Boro } \\
\text { paddy }\end{array}$ & 0.31 & 5.34 \\
\hline $\begin{array}{l}\text { Fibre } \\
\text { (Jute } \\
\text { and } \\
\text { mulber } \\
\text { ry) }\end{array}$ & 1.65 & 14.49 & Pulses & 1.63 & 14.31 & $\begin{array}{l}\text { Fibre } \\
\text { (Jute } \\
\text { and } \\
\text { mulberr } \\
\text { y) }\end{array}$ & 0.72 & 12.41 & $\begin{array}{l}\text { Pulse } \\
\mathrm{s}\end{array}$ & 2.12 & 36.55 \\
\hline Pulses & 1.05 & 9.22 & $\begin{array}{l}\text { Vegeta } \\
\text { bles }\end{array}$ & 1.79 & 15.72 & Pulses & 1.18 & 20.34 & $\begin{array}{l}\text { Veget } \\
\text { ables }\end{array}$ & 1.43 & 24.66 \\
\hline $\begin{array}{l}\text { Vegeta } \\
\text { bles }\end{array}$ & 1.25 & 10.97 & $\begin{array}{l}\text { Tamari } \\
\text { nd }\end{array}$ & 1.34 & 11.76 & $\begin{array}{l}\text { Vegetab } \\
\text { les }\end{array}$ & 1.12 & 19.31 & $\begin{array}{l}\text { Tama } \\
\text { rind }\end{array}$ & 0.86 & 14.83 \\
\hline Fallow & 2.02 & 17.73 & Wheat & 0.89 & 7.81 & Fallow & 1.5 & 25.86 & $\begin{array}{l}\text { Whea } \\
\mathrm{t}\end{array}$ & 0.21 & 3.62 \\
\hline & 11.39 & & Fallow & 4.91 & 43.11 & & & & $\begin{array}{l}\text { Fallo } \\
\text { w }\end{array}$ & 1.05 & 18.10 \\
\hline & & & & 11.39 & & & 5.98 & & & 5.98 & \\
\hline
\end{tabular}

Note: More than $50 \%$ mango orchard is cultivated in different seasons

Table 6: Temporal Pattern of Crop Combination, Diversification, Cropping Intensity

\begin{tabular}{|l|l|c|l|}
\hline Year & Crop Combination (Weaver's Method) & $\begin{array}{l}\text { Diversification (Entropy } \\
\text { Index; Berry's Index) }\end{array}$ & $\begin{array}{l}\text { Cropping } \\
\text { Intensity (CI) }\end{array}$ \\
\hline 1972 & $\begin{array}{l}\text { Multi cropping (Maize, Aman paddy, } \\
\text { tamarind, wheat, pulses, vegetable, } \\
\text { parble) CC }=15.83\end{array}$ & $\mathrm{EI}=0.68$ & $\mathrm{CI}=0.72$ \\
\hline 2012 & $\begin{array}{l}\text { Multi cropping (Maize, Aman paddy, } \\
\text { tamarind, wheat, pulses, vegetable, } \\
\text { parble, boro paddy) CC }=9.42\end{array}$ & $\mathrm{EI}=0.84$ & $\mathrm{CI}=1.57$ \\
\hline
\end{tabular}

\subsection{Population Migration}

Population migration from Naogharia village to newly developed Naogharia colony at the right side of present Active River and settlement expansion within oxbow lake circumscribed land are simultaneously going on. Serviceman, businessman, non agricultural labourer etc. are shifting to relatively safe places to avoid inaccessibility, and typical rural facility constrictions. In 1998, due to massive flood, erosion of land people of these groups has shifted to nearby towns or new colony outside the current course of river. Even some of the agricultural labourers have shifted themselves to the towns and changed their occupation from agricultural labour to either rick saw puller or labourer of the brick factory or masonnary workers. At present, over spilling rate has reduced, river course migration has resettled and in consequences with it migratory tendency of the people has also reduced. Direct and indirect agricultural workers have strongly bonded with soil and they have very least interest to shift some other places leaving their homeland.

\subsection{Settlement Dynamics}

Phase I(Before 1968): Naogharia village was at the right hand side of Kalindri river; Haripur village was circumscribed by $1^{\text {st }}$ oxbow lake; before cut off of $1^{\text {st }}$ oxbow, accessibility of Haripur village was fairly good, Most of the houses were composed with mud and thatch or Khalpa.

Phase II (1968-69): After neck cut of $2^{\text {nd }}$ oxbow, position of Naogharia village goes to left hand side of river Kalindri; Inaccessibility of Naogharia village gets increased; inaccessibility of the Haripur village has increased double times. About 25\% settlement of Naogharia and Haripur villages have shifted to Naogharia colony after straightening of river and formation of $2^{\text {nd }}$ oxbow lake.

In Phase III, one bridge has been made to connect Haripur and Naogharia. But current channel offers barrier against the accessibility of both the villages. Three fords help to cross the barrier. One bridge in current river course can help this isolated villages with mainland and it may encourage development process.

Massive inundation during 1998 in this region has also encouraged people to migrate to some other places.

Keeping parity with hydrological extremities, people are used to build up temporary or semi portable houses. These are basically made with mud, thatch, tiles, semi paccca constructions, houses made by pacaty (jute stick) etc. 


\section{Conclusion}

People's activities and attempts to adjust with changing drainage conditions are praiseworthy in this area. Apparently, shifting of river course may seem to be destructive in terms of resource base generation in this region but actually, this kind of change has added extra volume of resource extraction opportunity. So, slight change of outlook toward resource accounting and judgement, resource use will provide enough space to continue natural processes as usual. Always thinking should be drived in such ways so that nature can able to function naturally and economic opportunities can be sorted out and opted judiciously. This region is a good example where people have well adjusted with after change conditions. Use of wetland as fishing ground, aquaculture etc. way of crop culture, nature of crop diction, pattern of settlement etc. support the above statement. Instead of revert the natural function of drainage slight resettling of plan can resolute several problems.

\section{References}

[1] E.B.Barbier, A. Markandya, and D.W., Pearce, Environmental Sustainability and Cost-benefit Analysis. Environment and Planning. 22: 1990, 1259-1266.

[2] E.B. Barbier, The Economic Value of Ecosystems:1 - Tropical Wetlands. London Environmental Economics Centre, LEEC Gatekeeper Series 89-02, London, 1989b.

[3] E.B. Barbier, Valuing Tropical Wetland Benefits: Economic Methodologies and Applications. Geographical Journal. Part 1, 59, 1993, 22-32.

[4] E.B. Barbier, Valuing Environmental Functions: Tropical Wetlands. Land Economics. 70 (2), 1994, 155-73.

[5] Barbier, E.B., Adams, W.M. and Kimmage, K. An Economic Valuation of Wetland Benefits. In: Hollis, G.E., Adams, W.M. and Aminu-Kano, M. (eds). The Hadejia-Nguru Wetlands -environment, economics and sustainable development of a Sahelian floodplain. IUCN, Gland, Switzerland, 1993.

[6] Constantine, José; Dunne, Thomas, Meander cutoff and the controls on the production of oxbow lakes, Geology 36 (1), 2008.

[7] Hickin, Edward J. "Meandering Channels". In Middleton, Gerard V.. Encyclopedia of Sediments and Sedimentary Rocks. New York: Springer. 2002, p. 432.

[8] Majumdar, Dr. R.C., History of Ancient Bengal, first published 1971, reprint 2005, p. 4, Tulshi Prakashani, Kolkata.

[9] Merriam-Webster. Retrieved 2009-10-27.

[10] Oxford English Dictionary. Retrieved 2009-10-27.

[11] P.F. Scodari, Wetlands Protection: the Role of Economics, Environmental Law Institute Monograph, Washington, D.C. 1990.

[12] A. Strahler, \& A. Strahler, Physical Geography: Science and Systems of the Human Environment, John Wiley \& Sons, Inc., New York , 1996. 